\title{
Література:
}

1. Про платіжні системи та переказ коштів в Україні: Закон України від 05.04.2001 № 2346-III, Верховна Рада України. Відомості Верховної Ради України (ВВР), 2001, № 29, ст.137

2. Кравчук В. Електронні гроші в Україні. Аналітичний звіт / В. Кравчук, Д. Науменко, А. Глибовець. - К.: Альфа-ПІК, 2012. - 64 с.

3. Пояснювальна записка до проекту Закону України «Про віртуальні активи» від 14.09.2020, Народний депутат України Жмеренецький О.С.

4. Про запобігання та протидію легалізації (відмиванню) доходів, одержаних злочинним шляхом, фінансуванню тероризму та фінансуванню розповсюдження зброї масового знищення: Закон України від 06.12.2020 № 361-IX, Верховна Рада України. Відомості Верховної Ради України (ВВР), 2020. № 25. Ст. 171.

5. Про схвалення Концепції розвитку цифрової економіки та суспільства України на 2018-2020 роки та затвердження плану заходів щодо іiі реалізації: Розпорядження Кабінету Міністрів України від 17.01.2018 № 67-p.

DOI https://doi.org/10.30525/978-9934-26-074-2-33

\section{Е-ВИБОРИ В СУЧАСНОМУ ДЕМОКРАТИЧНОМУ ВРЯДУВАННІ}

\author{
Косілова О. I.
}

кандидат політичних наук, дочент, науковий співробітник

Інституту права

Київського начіонального університету імені Тараса Шевченка

\section{Федірко I. П.}

кандидат філософських наук, доцент, доцент кафедри політології філософського факультету

Київського національного університету імені Тараса Шевченка м. Київ, Україна

Пандемія COVID-19 істотно прискорила розвиток технологій i вплинула на роль цифровізації в цілому світі. 3 розвитком та розповсюдженням Інтернету з'явилися нові інформаційно-комунікаційні техно- 
логії, що відкрили можливості для безпосередньої участі громадян на політичному рівні. Сучасні діджитал-технології дозволяють особі не виходячи $з$ власного будинку здійснювати покупки, проводити інтернетконференції, он-лайн навчання, реалізовувати форми прямої демократії не виходячи з власного будинку й у будь-якій точці земної кулі.

Електронна демократія (Е-демократія) це порівняно нове явище у сучасному суспільстві. Ї̈̈ виникнення обумовлено стрімким розвитком інтернет технологій та штучного інтелекту. Зміст поняття «Е-демократія» можна тлумачити з двох позицій. У широкому розумінні «Е-демократія» означає залучення громадян до вирішення життєвоважливих суспільно-політичних завдань за допомогою сучасних інформаційних технологій. У більш вузькому розумінні «Е-демократія» передбачає застосування інформаційно-комунікаційних технологій (IKT) для забезпечення електронного супроводу прав громадян. У цьому разі змінюється лише технологічний бік подання заяв, звернень, запитів органам влади від імені громадян. Тобто, використовуючи своє законне право на отримання певної довідки, громадянин може звернутися до інстанції письмово, а може, наприклад, користуючись електронною поштою [1, с. 11].

Фактично засновником терміну «Е-демократія» можна вважати Е. Тоффлера, американського дослідника, одного 3 авторів концепції «інформаційної цивілізації», який вивчаючи особливості інтелектуалізації державного управління, вводить термін «кібердемократія». Науковець акцентує увагу на тому, що використання комп'ютерних технологій, мобільних телефонів і смартфонів, планшетів та інших робототехнічних засобів може стати основою для вироблення державою власних політичних рішень у тісній взаємодії з громадськістю [2].

Н. В. Грицяк вважає, що до складових електронної демократії можна віднести електронний парламент, електронне законодавство, електронний суд, електронне посередництво, електронні вибори, електронний референдум, електронне голосування, електронні петиції, електронні кампаніі, електронні опитування тощо». Кожна $з$ цих складових передбачає зацікавленість громадянина в результатах діяльності влади на всіх рівнях. Тому попереднім етапом е-залучення, очевидно, слід вважати залучення як таке [1, с. 32].

На наш погляд, одним 3 ключових елементів Е-демократії $є$ здійснення Е-голосування та застосування технологій штучного інтелекту (ШI)) під час здійснення виборчого процесу. Слід зазначити що в Україні ці технології поки що знаходяться на стадії розробки та потребують законодавчого врегулювання, хоча у багатьох зарубіжних країнах Ш широко застосовується, зокрема для проведення електронного голосування та швидкої обробки результатів виборів. 
Зокрема, на сьогоднішній день електронна система голосування вже запроваджена у багатьох країнах світу: США, Канаді, Бразилії, Індії, Бельгії, Австралії, Естонії, південній Кореї. У Великобританії, Німеччині, Франції, Іспанії, Португалії, Італії, Норвегії, Швейцарії, Росії, Казахстані, Японії, Китаї проводяться експерименти з їі використання [3].

Загалом, електронне голосування -це фіксація волевиявлення виборця $з$ використанням електронних технологій, що включає процес голосування і процес автоматичного підрахунку голосів за допомогою електронних пристроїв та спеціального програмного забезпечення [4]. Для української виборчої системи «електронне голосування» абсолютно нове явище, тому необхідно зрозуміти його сутнісні характеристики. Електронне голосування охоплює кілька різних типів голосування. При цьому воно охоплює як сам процес голосування за допомогою електронних засобів, так і процес автоматичного підрахунку голосів за допомогою електронних пристроїв та спеціального програмного забезпечення [5].

У світі вже застосовуються такі види процедур електронного голосування: віддалене голосування за допомогою Passport ID та інтернету; фізичне голосування на дільницях 3 підрахунком за допомогою електронних урн; голосування за допомогою спеціальних цифрових терміналів [6, с. 27].

У Свропі обладнання для голосування почали застосовувати в Нідерландах у 1969 році. На початку 1990-х років Міністерство внутрішніх справ цієї країни запровадило електронне голосування. У 2000 році майже 90\% виборців використали обладнання DRE. Однак внаслідок тиску з боку противників технології на виборах у 2008 році в Нідерландах повернулися до традиційних паперових бюлетенів [7].

Найбільш ефективний досвід впровадження інтелектуального управління у діяльності органів державної влади мала Естонія. У цій країні було вперше здійснено підрахунок голосів за допомогою використання електронних засобів, а сам процес взаємодії суспільства і органів влади здійснювався за допомогою комп'ютерної мережі. В Естонії електронне голосування застосовується з 2005 р. на місцевих виборах, 32007 р. на парламентських, під час яких 30275 громадян проголосували через Інтернет, не виходячи 3 домівок [8, с. 37]. Естонія у 2002 році ввела законодавчо електронний підпис, цифрові посвідчення особи ID-картки, споряджені кодом і мікрочіпом, що містить візуальні дані на картці, а також двома цифровими сертифікатами, призначеними для перевірки особи власника картки та надання цифрових підписів. На сьогодні більшість потенційних виборців мають електронні картки [9].

У США також застосовуються технологія для електронного голосування. Так, у більшості виборчих дільниць перфострічку замінили 130 
електронні машини для голосування, забезпечені системою touch-screen. Виборець повинен тільки кілька разів натиснути пальцем на екран й таким чином проголосувати. Ця нова технологія коштувала чотири мільярди доларів і введена на виборчих дільницях в 42 штатах $350[10$, c. 5$]$.

У Швейцарії, країні референдумів, близько 90\% виборців віддають перевагу традиційному методу голосування. Перші пробні електронні голосування відбулися у 2003 р. на комунальних виборах у кантоні Женева. У 2005 р. аналогічні пілотні проекти було реалізовано у кантонах Невшатель і Цюрих. Сьогодні така система частково охоплює виборців у 13-ти з 26-ти кантонів [11].

Україна поки що здійснює перші кроки у напрямку застосування системи електронного голосування. Починаючи з 2002-року, в тому чи іншому вигляді в Центральній виборчій комісії функціонує Єдина інформаційно-аналітична система «Вибори», покликана оперативно визначати попередні результати голосування [5].

На законодавчому рівні для цього ще не створено належного підгрунтя. Народним депутатом України О. I. Тищенком було подано проект постанови до Верховної Ради України стосовно впровадження «електронного голосування», який повинен забезпечити прозорість взаємодії уряду і громадян України [12], але до цього часу законопроект не був реалізований. Згідно 3 новим законом «Про народовладдя через всеукраїнський референдум» в Україні запроваджується можливість електронного голосування на референдумі. Визначення можливості запровадження електронних процедур під час організації та проведення всеукраїнського референдуму, в тому числі електронних голосувань $\epsilon$ ключовою новацією ухваленого закону, що вирізняє його серед інших ухвалених законів [13]. Зокрема, процедуру голосування за допомогою інтернет технологій врегульовано у ст. 101, п. 8, ст. 116 вищезгаданого закону [14].

Для забезпечення організації та проведення всеукраїнського референдуму закон передбачено створення автоматизованої інформаційноаналітичної системи щодо забезпечення електронного голосування. При цьому норми про введення процедур електронного голосування мають набути чинності з дня початку дії окремого закону про застосування інноваційних технологій, електронного (машинного) голосування [13].

Вітчизняне Міністерство цифрової трансформації реалізувало пілотний проект 3 «ПриватБанком» Smart-ID. Йдеться про ідентифікацію за електронним підписом, який зберігається не на чіпі, а на картці телефону. Таким чином, кожна особа може легко отримати засіб особистої ідентифікації. Така новація $є$ ще одним кроком уперед до 
запровадження системи електронного голосування. Але підпис у смартфоні не $\epsilon$ у достатній мірі захищеним від хакерських атак.

Таким чином, в умовах розвитку та вдосконалення механізхмів Е-демократії громадяни мають нові способи формування та участі в демократичних процесах. На нашу думку ці форми не можуть і не повинні замінити класичну представницьку та безпосередню демократію, але мають використовуватися як додаткові форми для підвищення рівня політичної участі громадян у сучасних умовах. Карантинні обмеження пов'язані $з$ пандемією COVID-19 підтверджують необхідність та своєчасність застосування таких форм. Вважаємо, що нові онлайн-інструменти здатні не лише автоматизувати і прискорити процеси, а й зробити процедури більш прозорими і відкритими, що важливо для підвищення довіри громадян до інституту влади.

\section{Література:}

1. Грицяк Н. В., Соловйов С. Г. Електронна демократія як механізм політичної взаємодії: навч.-метод. рек. К.: НАДУ, 2013. 44 с. URL: http://academy.gov.ua/NMKD/library_nadu/Monografiy/c25fded6553e-4264-8a5e-3a14cea16bfc.pdf (дата звернення: 10.04.2021).

2. Тоффлер Е. Третя хвиля / Е. Тофлер. - К.: Видавничий дім «Всесвіт». 2000. -480 c.

3. Питання впровадження електронної системи голосування. Державне будівниитво та місиеве самоврядування в Украӥні. URL: http://proeto.com.ua/pravo/derzhavne-budivnictvo-i miscevesamovryaduvannya-v-ukrayini/pitannyavprovadzhennya (дата звернення: 02.03.2021).

4. Караваєв І. Вибори онлайн в Україні: реалії та перспективи. URL: https://yur-gazeta.com/publications/practice/informaciyne-pravo-telekomunikaciyi/vibori-onlayn-v-ukrayini-realiyi-ta-perspektivi.html

(дата звернення: 02.03.2021).

5. Ярова А.П. Електронні вибори в естонії: досвід для України. URL: https://conferences.vntu.edu.ua/index.php/e-democracy/e-democracy 2016/paper/viewFile/1694/1384 (дата звернення: 04.03.2021).

6. Судрієтт p. У. Технології голосування: життєво важливий інструмент для учасників виборів. Вісник Центральної виборчої комісії. № 3 (27) 2013 p. C.27-29 URL:https://www.cvk.gov.ua/wp-content/uploads/ 2020/05/2013_3_visnik_title.cvk_.pdf (дата звернення: 10.04.2021)

7. Переглянута Європейська хартія участі молоді в громадському житті на місцевому та регіональному рівні. URL: http://eucharter.pedagog.org.ua/text/charter/src.html (дата звернення: 10.04.2021).

8. Зарубіжний досвід упровадження електронного урядування / за заг. ред. С.А. Чукут. К., 2008. - 200 c. https://ktpu.kpi.ua/wp-content/ 132 
uploads/2016/02/Zarubizhnij-dosvid-uprovadzhennya-elektronnogouryaduvannya.pdf (дата звернення: 10.04.2021).

9. Электронная демократия: граждане и власть. URL: http://imrussia.org/ru/society/330-e-democracy-citizens-and-the-state (дата звернення: 10.04.2021).

10. Системи електронних виборів: процедури голосування та матеріальнотехнічні засоби. Міжнародний досвід. Інформаційна довідка, Європейський інформаційно-дослідницький центр, 10 с. URL: http://euinfocenter.rada.gov.ua/uploads/documents/28966.pdf (дата звернення: 10.04.2021).

11. Прямая демократия Швейцарии в цифровую эпоху URL: http://www.swissinfo.ch/rus/detail/content.html?cid=36670692\&link=ct о (дата звернення: 10.04.2021).

12. Про Концепцію «Запровадження системи електронного голосування в Україні»: проект закону України від 10.06.2011. URL: https://ips.ligazakon.net/document/JF6OG00A (дата звернення: 10.04.2021).

13. В Україні ухвалили новий закон про референдум URL:https://www.dw.com/uk/v-ukraini-ukhvalyly-novyi-zakon-pro-referendum/a-56349619

14. Про народовладдя через всеукраїнський референдум: Закон України від 26.01.2021 № 1135-IX URL:http://w1.c1.rada.gov.ua/pls/ zweb2/webproc4_1?pf3511=69060 (дата звернення: 10.04.2021).

DOI https://doi.org/10.30525/978-9934-26-074-2-34

\title{
HARMONIZATION OF UKRAINIAN LEGISLATION ON VERTICAL CONCERTED ACTIONS WITH THE COMPETITION LEGISLATION OF THE EUROPEAN UNION
}

\author{
Kravtsova I. A. \\ Postgraduate Student at the Department \\ of International Law and Comparative Law \\ National University of Life and Environmental Sciences of Ukraine \\ Kyiv, Ukraine
}

The principle of freedom is the most important principle of law [1]. It is fundamental for determining the scope of human rights and freedoms and it determines the nature of a person's behavior in legal relations [2]. Freedom of contract is one of the principles that belongs to the general principles of civil 